\title{
Determining how the pelagic ecosystem over the continental shelf of the Bay of Biscay (NE Atlantic) functions: An approach using mesozooplankton enzyme activities as descriptors
}

\author{
Jean-Pierre Bergeron ${ }^{a,}{ }^{*}$, Daniel Delmas ${ }^{b, 1}$ and Noussithé Koueta ${ }^{c}$
}

\begin{abstract}
a IFREMER, Département Ecologie et Modèles pour l'Halieutique (EMH), Centre de Nantes, Rue de l'lle d'Yeu, B.P. 21105, F-44311 NANTES CEDEX 03, France

b IFREMER, Centre de Recherche sur les Ecosystèmes Littoraux Anthropisés (CRELA), Laboratoire de La Rochelle, B.P. 7, F-17137 L'HOUMEAU, France

${ }^{c}$ Université de Caen, Laboratoire de Biologie et Biotechnologies Marines, Esplanade de la Paix, F-14032 CAEN CEDEX, France

${ }^{1} \mathrm{New}$ and present address: Département Dynamique de l'Environnement Côtier (DYNECO), IFREMER, Centre de Brest, B.P. 70, F-29280 PLOUZANE, France.
\end{abstract}

*: Corresponding author : J.-P. Bergeron, email address : Jean.Pierre.Bergeron@ifremer.fr

\begin{abstract}
:
A fisheries research cruise conducted in 2000 offered a first opportunity to take simultaneous measurements of the activities of three enzymes in mesozooplankton samples collected at a regional scale over the continental shelf of the Bay of Biscay in the NE Atlantic, with the aim of characterizing main aspects of the functioning of the biotic environment of small pelagic fish populations. The activity of the digestive endopeptidase trypsin was selected to characterize the assimilation rate of proteins, whereas pyruvate kinase (PK) was chosen as an indicator of carbohydrate assimilation and aspartate transcarbamylase (ATC) provided an overall assessment of mesozooplankton productivity. The Bay of Biscay region is subject to various strong physical driving forces that directly affect the primary structure of the pelagic food web. On our cruise, the phytoplankton biomass distribution reflected these different physical influences: diatoms dominated the nutrient-enriched coastal water; picoplankton dominated the northern-central part where nutrients were depleted; and nanoplankton were abundant at the shelf break where internal waves provided an input of nutrients. These and other results (on bacteria, particulate organic carbon distribution, among others) illustrate the differences that exist in the microbial food webs of different sectors of the bay. The living matter produced was characterized by the quality and quantity of the smallest prey items that were available to higher trophic levels. Variations in mesozooplankton enzyme activities may agree well not only with classically expected results, but also present unexpected special features: high ATC specific activities were measured around the mouth of the Gironde, in the nutrient-rich desalted water of the plume, but surprisingly not in front of the Loire river. PK specific activities reflected preponderantly the balance between phytoplankton cells sizes and the related bacterial abundance resulting from nutrient limitation (mainly P), that induces varying carbohydrates production potential. Trypsin specific activities were moderately variable, except in a restricted area where a highly abundant protein content characterized the particulate matter and in the plume of water flowing out of the Gironde. It is concluded that the presented approach of the metabolism of mesozooplankton communities may provide novel views on crucial processes occurring at the mesoscale, which fits in generally well with the scales of ecological factors mostly influential on small pelagic fish populations.
\end{abstract}

Keywords: aspartate transcarbamylase; Bay of Biscay; mesozooplankton; metabolic descriptors; pyruvate kinase; trypsin 


\section{Introduction}

80 Pelagic marine systems have quite different characteristics according to their location in 81 the world's ocean. As recently demonstrated for the Bay of Biscay in the NE Atlantic 82 (Bergeron, 2004), the pelagic environment over its continental shelf experiences many extrinsic physical drivers. It is a patchwork of different ecosystems, including (1) coastal

84 systems influenced either by river plumes or local upwelling caused by special wind regimes and (2) oceanic systems along the shelf break, where deep water may be up-welled or large eddies may form. The resulting diversity of environmental conditions generates special adaptations in food web structures and varying functional rates, which affect the mesozooplankton communities inhabiting these systems (Albaina and Irigoien, 2004; 2007). Different environmental conditions can result in substantially different mesozooplankton species composition, biomass, and metabolism (e.g. Bergeron, 2004;

91 2006). Mesozooplankton, which prey on small particles such as phytoplankton and 92 protozoans, in turn serve as prey for the abundant small pelagic fishes. Thus, following 93 Banse (1995) (although he included heterotrophic protozoans in the more general term "zooplankton"), one may consider that mesozooplankton (sensu Sieburth et al., 1978) play a "pivotal role in the control of ocean production".

97 The bulk of mesozooplankton consist of copepods; these small crustaceans often constitute as much as $80 \%$ of the biomass, and often even more for the Bay of Biscay (i.e., 92-98\%

99 according to Plounevez and Champalbert, 1999). Copepods are probably the most

100 numerous multicellular organisms on earth (Mauchline, 1998). Marine copepods form a

101 relatively homogeneous zoological group, occupying a strategic place in pelagic food webs. Moreover, some aspects of their life cycle are especially interesting, such as their 
103 permanence and omnipresence in marine systems and the fact that their generation time fits

104 in generally well with the duration of mesoscale events and spatial structures occurring in

105 pelagic systems. Such mesoscale events and features are often those most crucial for the

106 study of the environment of marine fish populations. The position of the mesozooplankton

107 in the complex organisation of pelagic ecosystems suggests their importance for generating

108 an integrated view of the channelling of energy and organic matter through the autotrophic

109 and heterotrophic components of the pelagic food web into marine resources, both to direct

110 consumers of mesozooplankton and to predators higher in the ecological hierarchy.

112 With the aim of easily assessing basic processes in pelagic ecosystems, a number of

113 conceptual assumptions (Bergeron 1983; 1986; 1995) have been advanced to justify

114 enzymatic activity measurements of samples of the whole mesozooplankton community.

115 While it must be acknowledged that such methods are grounds for some criticisms (e.g.,

116 Berges et al., 1993), interest in their implementation endures because they provide the

117 fastest, simplest, and least expensive means of assessing mesoscale variations in important

118 metabolic features (e.g., Packard et al.'s (1996) study of ETS activity for estimating the

119 respiration process). The use of such methods is especially important from a fisheries

120 research perspective, because synoptic cruises must generally be performed over broad

121 areas as quickly as possible; this is notably the case for the ecological studies of small

122 pelagic fish populations carried out by our research team in the Bay of Biscay (Scalabrin

123 and Massé, 1993).

125 The fundamental basis of enzymatic methods is their specificity with regard to the targeted

126 metabolic process. If uncertainties about the reliability of such an approach persist from a

127 fundamental view of biochemical practice, the hope is that assessing enzyme activities is 
essentially monitoring rates of realization of metabolic steps. Accepting that stoichiometric

129 relationships between enzyme activities measured in a sample of the whole

130 mesozooplankton community and the ecosystem rates of specific metabolic processes are

131 most probably out of reach, nevertheless enzyme activities theoretically express a dynamic

132 view of the processes involved (i.e., they have the dimension of $t i m e^{-1}$, which is a highly

133 valuable property). Therefore, an enzyme's activity can be used as a proxy for a metabolic

134 process; it is an index that uses relative values, which permits comparisons of samples

135 taken in the marine area under study.

136

137 The goal of this study was to measure the activities of three enzymes to assess two main

138 processes: (1) the transfer of particles into the mesozooplanktonic compartment by feeding,

139 and (2) the secondary productivity resulting from the assimilation of food. Proteins and

140 carbohydrates are two of the main components of living particulate organic matter, and

141 they represent the largest quantity of the food ingested by copepods. Protein ingestion and

142 assimilation have been classically estimated through the activity of the digestive enzyme

143 trypsin, as initially suggested by Boucher et al. (1976) and measured by many others (e.g.,

144 Båmstedt, 1988; Hirche, 1989; more recently Lischka et al., 2007). Because of the

145 diversity of the macromolecular structure of carbohydrates, their crude molecules require

146 specific digestive enzymes to be assimilated in a first step (cf. p. 168, Table 4.1., in

147 Mayzaud, 1986). In this study, we did not follow the methods based on digestive enzymes

148 used by previous authors (cf. Mayzaud, 1986), but preferred measures of pyruvate kinase

149 (PK) activity, according to concepts advanced by Bergeron and Herbland (2001), as an

150 indicator of carbohydrate assimilation. PK operates at the end of the glycolysis chain, an

151 intracellular catabolic pathway common to all classes of carbohydrates. Finally, the overall

152 bulk mesozooplankton productivity was estimated with aspartate transcarbamylase (ATC), 
153 an enzyme involved in the biosynthesis of pyrimidine bases used to build nucleic acids for

154 cell multiplication and protein synthesis. In short, trypsin activity should indicate protein-

155 rich diet assimilation by mesozooplankton (dominance of a microbial loop or presence of

156 heterotrophic protozoans for instance, among other protein-rich food items); PK activity

157 should indicate carbohydrate assimilation (grazing on phytoplankton, or other

158 carbohydrate-rich prey); and ATC activity should permit the characterization of the overall

159 mesozooplankton productivity resulting from the assimilation of these two classes of

160 molecules.

161

162 We present here the results of our first opportunity to measure activities of all three

163 enzymes simultaneously in the same mesozooplankton samples collected over a relatively

164 large scale (about $4^{\circ}$ in latitude) across the continental shelf of a temperate area in spring

165 of the year 2000. Petitgas et al. (2006) previously incorporated these enzyme activities into

166 a set of more than fifty variables, permitting data processing based on statistics. Their aim

167 was to cluster stations according to different hydroplankton characteristics in an attempt to

168 define the environment of two populations of small pelagic fish in the Bay of Biscay. We

169 reconsider these data here in an alternative spirit, in a more naturalistic way, in search of a

170 way to characterize different food web functional types and rates of channelling matter and

171 energy from primary producers (here defined as phytoplankton and bacteria) to higher

172 trophic levels. The ultimate target of the present work is determining to what extent this

173 small set of three enzyme activities is able to give a coherent and reliable picture of the

174 overall functioning of the pelagic ecosystem providing useful information on the factors

175 influential on the zooplanktivorous small pelagic fish populations of the Bay of Biscay. 


\section{Materials and methods}

178

179 The PEL2000 research cruise, which also was devoted to the study of the abundance and

180 spatial distribution of small pelagic fishes using acoustic tools (Scalabrin and Massé,

181 1993), occurred from April 17 to May 13, 2000 aboard the RV Thalassa. It covered the

182 entire French part of the continental shelf of the Bay of Biscay (i.e., a little more than $4^{\circ}$ in

183 latitude). Mesozooplankton sampling occurred at stations located along transects that ran

184 roughly perpendicular to the coast line: 69 mesozooplankton samples were collected

185 (Figure 1).

186

187 Water samples

188 Water samples were collected at five depths for measurements of nutrients, chlorophyll,

189 bacteria, and particulate organic carbon (POC), following a reduced sampling grid (46

190 stations, cf. Figure 1). The methods used for nutrient and primary producer analyses

191 followed Petitgas et al. (2006) and will not be described here. Phytoplankton carbon was

192 estimated from Chl $a$ concentrations assuming a constant C:Chl $a$ ratio of 50:1; bacterial

193 numbers were converted into bacterial carbon assuming a standard cell content of $16 \mathrm{fg} \mathrm{C}$

194 that corresponds to the range of values (10-18 fg C) previously measured by Artigas

195 (1998) in the Bay of Biscay. Because phytoplankton and bacteria constitute the main

196 component of the microbial assemblage, we assumed that their carbon represented an

197 approximation of the microbial carbon.

198 We determined two ratios from these data:

199 (1) (microbial C)/POC gives a picture of the living carbon in micro-organisms in relation

200 to the total POC. The difference, total POC - microbial C roughly represents detrital

201 carbon. 
202 (2) (bacterial C)/(phytoplankton C) represents an index of ecosystem development through

203 different physiological states of the phytoplankton community.

Mesozooplankton samples and enzyme analyses

206 Mesozooplankton samples were collected by $50 \mathrm{~cm} \mathrm{sec}^{-1}$ vertical tows with a WP2 net

207 (200- $\mu \mathrm{m}$ mesh size) from the bottom (or from $200 \mathrm{~m}$ depth in the case of the few stations

208 located in the oceanic province) to the surface. On board, the macrozooplankton collected

209 were separated by sieving through a 5-mm mesh. The mesozooplankton in the

210 filtrate were homogenised in iced distilled water with a Polytron ${ }^{\circledR}$ grinder. Then, 2.5-ml

211 aliquots were immediately frozen in liquid nitrogen and kept in liquid nitrogen until the

212 end of the cruise. Thereafter, they were stored at $-80{ }^{\circ} \mathrm{C}$ until analysis in the laboratory, as

213 this storage procedure does not introduce any significant change in enzymatic activities

214 (Biegala and Bergeron, 1998). After thawing, the crude extract was homogenised again

215 with a Potter-Elvehjem tissue grinder, and a 200- $\mu$ l aliquot of the resulting homogenate

216 was reserved for the ATC activity assay. The rest of this homogenate was centrifuged (10

$217 \min$ at $4000 \mathrm{rev} \min ^{-1}, 3^{\circ} \mathrm{C}$ ) and $200-\mu 1$ aliquots of the supernatant fluid were assayed for

218 other enzymes or for protein content. Trypsin activity was estimated by the classical

219 "BAPNA method" adapted to zooplankton extracts by Samain et al. (1977), pyruvate

220 kinase activity according to Bücher and Pfleiderer (1955), modified by Bergeron and

221 Herbland (2001), and ATC activity as initially described by Bergeron and Alayse-Danet

222 (1981) and revised by Biegala and Bergeron (1998).

224 PK specific activity is expressed in $\mu \mathrm{M}$ NADH oxidised $\mathrm{min}^{-1} \mathrm{mg}^{-1}$ protein;

225 trypsin specific activity in $\mu \mathrm{M} p \mathrm{NA}$ (paranitroaniline) released $\mathrm{min}^{-1} \mathrm{mg}^{-1}$ protein; and

226 ATC specific activity in nM CA (carbamylaspartate) produced $\mathrm{min}^{-1} \mathrm{mg}^{-1}$ protein. 
227 In the figures below, specific activities of enzymes measured in mesozooplankton samples

228 are presented as square symbols. For each enzyme, three classes of values were arbitrarily

229 defined according to the frequencies of these values in each class in order to have a well-

230 balanced distribution. 


\section{Results}

232

233

\section{Hydrobiological environment}

234 Among the strong physical drivers in the Bay of Biscay, two are permanent but vary in their effects according to seasonal conditions. Moreover, they exert opposing influences

236 because one brings freshwater, the other high salinity waters. However, they both provide

237 inorganic nutrients to surface waters over the Bay of Biscay shelf. First, two large rivers,

238 the Loire and the Gironde, debouch into the middle-northern part of the region. There is

239 also a smaller river in the south, the Adour, which is generally at its outflow maximum

240 during the breeding season (around May) of the anchovy population; this is water issuing

241 from the spring thaw of snow in the nearby Pyrenees Mountains. The influx of freshwater

242 is clearly indicated by the low salinity of surface waters along the coast (Figure 2). The

243 consequent enrichment in inorganic nutrients (e.g., nitrate, cf. Figure 3) is also evident in

244 the coastal area. The spatial variations of nitrate concentration in surface waters (Figure 3)

245 show that another source of nutrients exists over the shelf break, the up-welling of deep

246 waters (highest surface salinity for the region, 35.6) induced by strong tidally induced

247 internal waves. The phenomenon is revealed by satellite imagery (Figure 4 shows a view at

248 the same stage of the seasonal cycle, though not from the year of the cruise; Gohin et al.

249 (2005) demonstrated that this process is recurrent, at least for the period 1998-2003 and

250 that the picture presented is reliably representative) and its effect on primary production, in

251 terms of $\mathrm{Chl} a$, appears clearly in a vertical hydrological section along the continental

252 slope (Figure 4). This surface layer enrichment plays a prominent role in this oceanic-like

253 part of the bay. From satellite imagery, it is possible to infer that an area $\sim 50 \mathrm{~km}$ wide and

254 several hundred $\mathrm{km}$ long and over a depth of about $40 \mathrm{~m}$ is enriched by this internal wave 255 process. 
257 The size structure of the phytoplankton community can be described by three categories:

258 microphytoplankton (cells > $20 \mu \mathrm{m}$ ); nanophytoplankton (cell sizes between 3 and $20 \mu \mathrm{m}$ );

259 and picophytoplankton (cells $<3 \mu \mathrm{m}$ ). Microphytoplankton, which is essentially composed

260 of diatoms, dominated in nutrient-enriched coastal waters and in the southern part of the

261 bay (Figure 5). Nanophytoplanktonic cells were mainly present in the northwest.

262 Picophytoplankton were absent along the coast but were abundant in the northern and

263 central part of the bay. In this latter area, nutrients were almost exhausted (Figure 3) and

264 picophytoplankton were dominant. The low percentage of microbial carbon (Figure 6)

265 suggested that the POC was essentially detrital. The bacterial biomass was high in

266 comparison with the phytoplankton biomass ( $>25 \%$, cf. Figure 7), which indicated that a

267 microbial loop was actively operating and that regenerated production was significant.

Mesozooplankton enzymatic indices

270

PK specific activities did not appear to be enhanced by inflow of nutrient-rich freshwater

271 from rivers in coastal areas (Figure 8a), despite conditions favourable a priori for

272 stimulating photosynthetic carbohydrate production. Conversely, stations along the shelf-

273 break exhibited some of the highest PK activities, which were probably enhanced by ingestion of phytoplankton cells enriched in carbohydrates produced by active photosynthesis through the supply of nutrients in up-welled deep waters; here PK activities were clearly influenced by variations in phytoplankton biomass in terms of Chl $a$ (Figure 4). However, a highly significant correlation $(\mathrm{R}=0.639, \mathrm{DF}=45, p<0.001)$ linked the spatial variations of PK specific activities to the ratio of (bacterial C)/(phytoplankton $\mathrm{C}$ ), and this relationship was valid for all of the stations sampled during the cruise. 
281 A small group of four stations in the northwest sector of the sampled area (in the region of

$28247^{\circ} \mathrm{N}, 5^{\circ} \mathrm{W}$; see open circles in Figure 1 that specify the positions accurately) exhibited

283 some of the highest values of trypsin specific activity (Figure $8 \mathrm{~b}$ ). The mean value for

284 these stations was $5.77($ S.D. $=0.18)$, whereas the mean for the whole ( 82 stations) was

$2854.10($ S.D. $=1.03)$; these four stations were situated close to the one where the water

286 column sampling had the highest value of integrated particulate protein: $3.81 \mathrm{~g} \mathrm{~m}^{2}$. The

287 mean for the other 44 hydrobiological stations was $1.64($ S.D. $=0.34)$. Such a strong

288 coincidence is worth noting. Except for this special case, trypsin activities did not vary

289 greatly across the bay as a whole. There were, however, three high values along the coast,

290 especially in less saline water flowing from the Gironde estuary (Figure 2); this difference

291 could be related to the higher abundance of detrital POC in this water (Figure 6), as

292 mentioned above.

293

294 Theoretically, ATC specific activities reveal the global productivity of mesozooplankton

295 communities and should be partly conditioned by the efficiency of primary processes

296 represented by the enzymes PK and trypsin. The ATC activities were weak everywhere in

297 the Bay of Biscay, except over the shelf break and along the coast, where moderate or high

298 values were observed (Figure 8c). Taking into account the width of the area enriched by

299 up-welled deep waters along the shelf break, it may be considered that the two high and

300 four moderate values of ATC activity in this area resulted from this enrichment. Along the

301 coast we found the highest ATC activities, and these were related to less saline waters

302 entering from rivers. Moderate activities were not much lower than the highest ones,

303 especially in front of the mouth of the Gironde estuary. In contrast, the stations around the

304 mouth of the Loire River did not show any remarkable features. It should be noted that,

305 along the coast, ATC activity variations were somewhat correlated with those of trypsin 
306 and were inversely related to the mean values of the (microbial C)/POC ratio found in the

307 three major plumes (shown in Figure 6) estimated for waters influenced by freshwater 308 from the rivers. 


\section{Discussion}

310

311 A highly important point has to be raised first, as a preliminary of the discussion section.

312 Phytoplanktonologists and zooplanktonologists generally do not use the same language,

313 i.e. similar expressions to present their descriptors. This is because the spatial variation

314 scales are strongly different and most of the small particles (in a generic sense) they study

315 often are presented as integrated values $\left(\right.$ per $\mathrm{m}^{2}$ ) for the photic layer in the case of particles

316 produced at the primary level. In contrast, because of the well-known patchiness

317 distribution of zooplankton (e.g. Steele, 1977; Williamson et al., 1986), their descriptors

318 must be related to a weight-linked reference, i.e. dry weight or, as in the present study,

319 protein content. Otherwise, an expression of enzyme activities analogous to that of primary

320 producers (per $\mathrm{m}^{2}$ ) would be essentially representative of values influenced by spatial

321 variations of zooplankton biomass. For this reason, formal relationships valid for the whole

322 studied region between both main types of descriptors are difficult to establish, in

323 particular to test statistically, except for instance in the case of the bacterial C /

324 phytoplankton $\mathrm{C}$ ratio, which is typically a descriptor based on relative values. A statistical

325 treatment of this data set has been previously presented by Petitgas et al. (2006). These

326 data are reconsidered here in an alternative spirit: what the hydrobiological descriptors tell

327 us about the structure and functioning of the pelagic ecosystem and how the

328 mesozooplankton communities adapt to this environment.

\subsection{Significance of the metabolic descriptors}

332 Among the three descriptors used in the present study, PK activity is the newest enzymatic

333 tool for evaluating the metabolic ecology of mesozooplankton. It was initially promoted

334 with the hope of obtaining a global assessment of carbohydrate assimilation by

335 mesozooplankton (Bergeron and Herbland, 2001). The underlying concept was that the 
336 generic reaction occurring under the catalytic action of chlorophyll may be summarized as

$337 \mathrm{CO}_{2}+\mathrm{H}_{2} \mathrm{O} \rightarrow \mathrm{HCHO}+\mathrm{O}_{2}$, where $\mathrm{HCHO}$ symbolizes the basic elemental ratio of

338 carbohydrates. However, phytoplankton actively growing in exponential phase are also

339 very rich in protein (Haug et al., 1973; Granum et al., 2002); this could explain why large

340 phytoplankton cells in the river plumes did not contain carbohydrate in sufficient quantity

341 to induce enhanced PK activity. The observed correlation between PK specific activities

342 and the ratio of bacterial $\mathrm{C}$ to phytoplankton $\mathrm{C}$ suggests a highly valuable significance of

343 PK specific activity: it is able to provide an overall view of ecosystem development

344 through different physiological states of the phytoplankton community. This ratio is low

345 when phytoplankton are blooming in nutrient replete waters (Cho and Azam, 1990; Simon

346 et al., 1992). In contrast, the ratio is high in post-bloom periods, when phytoplankton are

347 severely nutrient limited. Under nutrient limitation ( $\mathrm{N}$ or $\mathrm{P}$ ), phytoplankton cells respond

348 with high production of both particulate and dissolved carbohydrates, in relation to

349 proteins, and carbohydrates are favourable to development of bacteria (Granum et al.,

350 2002; Børsheim et al., 2005). During such post-bloom periods, regeneration processes

351 control phytoplankton growth. The potential interest of PK application has previously been

352 demonstrated in a special case of very low enrichment in nutrients of a river plume

353 (Bergeron, 2006). Anyhow, the significance of enhanced carbohydrate assimilation by

354 mesozooplankton through an increase of the PK specific activity does not seem to be

355 fundamentally disputable from a theoretical point of view.

357 Certainly it is dangerous to draw definite conclusions from one single data set;

358 nevertheless, in the present study high PK activities occurred in locations where

359 mesozooplankton could graze on large phytoplankton cells (> $20 \mu \mathrm{m}$ ) under conditions

360 apparently permitting new production: enhanced PK activity occurred in such conditions in 
361 the south of the bay, but also where phytoplankton were small and nutrient limited, a

362 condition favourable to hyper-production of carbohydrates according to an abundant

363 literature (e.g., Granéli et al., 1999; Alderkamp et al., 2006). Between these two radically

364 contrasting ecological contexts, intermediate situations obviously contribute to the global

365 correlation that links variations in PK specific activities to the ratio of bacterial $\mathrm{C}$ to

366 phytoplankton C. A continuum exists, like that advanced by Legendre and Rassoulzadegan

367 (1995), between two contrasting pathways for the flux of biogenic carbon (i.e., the

368 herbivorous and the microbial food webs). Therefore, results from PK activity

369 measurements in mesozooplankton might require to be interpreted cautiously, at least with

370 respect to evaluating assimilation of autotrophic cells.

372 But in another respect, one may wonder what is the most important information to obtain 373 about the function of a pelagic ecosystem. Is it crucial to demonstrate that a certain type of 374 phytoplankton cells constitutes a principal food source to mesozooplankton compared to 375 other types, or can the process be viewed from another angle, as recommended in recent 376 essays on ecological thinking (Whitfield, 2004): with respect to the purely metabolic

377 process, the essential question is what quantity of carbohydrates enters the mesozooplankton compartment, a pivotal link of the pelagic food web (in accordance with Banse, 1995). The basic concept may be restated: a measurement of PK activity in a mesozooplankton sample evaluates a process working at the cellular level (i.e., the

381 functional rate of the last enzyme of the glycolysis chain, which depends on the

382 assimilation of all ingested carbohydrates).

384 In the estuary plumes, we found relatively high activities of trypsin in accordance with the 385 richness in protein of actively growing autotrophic cells. However, living particles do not 
offer a sole type of prey for mesozooplankton (e.g., Poulet, 1976) and another source of organic matter might explain high trypsin and ATC activities. For example, the suspended particulate matter (SPM) present in estuarine waters to variable extents (Tackx et al., 1995;

Gasparini et al., 1999) may play, with associated micro-organisms and notably ciliated

390 protozoans, an important role in copepods feeding (Heinle et al., 1977). As recently

391 pointed out (Håkanson, 2006), the carbon content of SPM is crucial at low trophic levels:

392 the SPM in the water column is also a metabolically active component of the food web. In 393 our study, the Gironde estuary is well known for its high levels of SPM (e.g., Castel and

394 Feurtet, 1989; David et al., 2005) mainly made up of a large fraction of particulate organic 395 carbon (Irigoien and Castel, 1995). This could explain why the (microbial C)/POC ratio is 396 in front the Gironde estuary is the lowest out of the three estuaries, it means that the POC 397 is essentially detrital, it is quite in agreement with the generally accepted concept of the 398 Gironde carrying seaward much more SPM than does the Loire estuary. Accordingly, we 399 also found large differences in the trypsin and ATC activity levels in mesozooplankton 400 collected immediately offshore from them. Thus, we hypothesize that detrital matter 401 released from rivers induces a strong local enhancement of mesozooplankton productivity, 402 as revealed by high ATC specific activities, particularly offshore of the Gironde estuary. 403

404 In contrast with coastal mesozooplankton, which are contained along the coast by a residual circulation driving waters to the north (cf. isohalines in Figure 2), the up-welled 406 deep waters along the shelf break tend to spread beyond the slope, inducing a relatively 407 wider but more diluted enrichment, which is revealed by the extent of higher nitrate 408 concentrations at the surface. This phenomenon has an effect on PK activity and to a lesser 409 extent on trypsin. The consequence for ATC activity appears to be a dilution effect; we 410 found two high values on the fringe of the area concerned. 
412 All of the data presented in this study were gathered during a fisheries research cruise

413 devoted to small pelagic fishes in the Bay of Biscay. Abundance and spatial distribution of

414 these populations were estimated through acoustic tools (Jacques Massé, Dept. EMH,

415 IFREMER, Manager). Sardines (Sardina pilchardus) and anchovies (Engraulis

416 encrasicolus) are by far the dominant small pelagic species in this region, and results of

417 this investigation provide indices about spatial variation of pelagic productivity (Figure 9).

418 Anchovies mainly accumulate along the southeastern part of the coast, whereas sardines

419 are more scattered throughout the bay, with low abundance in the south, greater abundance

420 in the middle-northern part along the shelf break, and only a few echoes detected in the

421 northeast along the coast. Anchovies are strictly zoophagous throughout their life.

422 Although small sardines (no longer than $18 \mathrm{~cm}$ ) also are zoophagous, as they grow they

423 develop a filter feeding system, and individuals longer than $18 \mathrm{~cm}$ become

424 phytozoophagous, or mixed feeders (Garrido et al., 2007). Sardines show differential

425 behaviours according to their size: Small individuals live in surface layers and larger

426 individuals live in deeper layers (Jacques Massé, Dept. EMH, IFREMER, pers. comm.).

427 Therefore, anchovies and small sardines occur in relatively shallow waters in coastal areas.

428 In the open sea, and especially over the shelf break, anchovies are scarce, small sardines

429 live in surface layers, and large sardines inhabit deeper layers where they feed on the deep

430 phytoplankton (as indicated by the presence of Chl $a$, cf. Figure 4). The greatest abundance

431 of the carnivorous anchovy occurred near the mouth of the Gironde estuary (Figure 9),

432 which most likely indicates a strong attractive effect of the enrichment of the adjacent

433 marine area upon the breeding anchovy population. This is in itself an index of

434 zooplankton productivity, which also is clearly supported by high ATC activities.

435 Accumulation of anchovy biomass coincident with high ATC activities extended to the 
southern part of the bay (i.e., from $44^{\circ} 30 \mathrm{~N}$ until the northern limit of low salinity coastal

437 water flowing out from the Gironde).

438

439 The respective distributions of the two fish species illustrate that the central-northern part

440 of the bay is a biological desert in regard to fish spawning in spring, an observation made

441 often in previous years and even over several decades (Arbault and Lacroix, 1977). From

442 recent work on the typology of hydrological structures over the Bay of Biscay shelf,

443 Planque et al. (2006) characterized six main hydrological zones, of which one presents

444 strongly distinctive features, notably a deep mixed layer and the greatest stability over

445 time. This zone coincides with the desert, where surface nutrients are almost exhausted,

446 picophytoplankton are dominant, and high PK specific activities were measured in

447 mesozooplankton samples in this study. In this nutrient-limited area, small-sized

448 phytoplankton cells control regeneration production and the apparent hyper-productivity of

449 carbohydrates is linked to an actively working microbial loop. However, the final

450 disposition in the ecosystem of the excess carbohydrate production implied by the

451 enhanced PK activity is unknown, at least so far as the pelagic ecosystem is concerned.

452 This hydrographic zone coincides with La Grande Vasière, a benthic area well known by

453 fishermen for its enhanced biological productivity and where intense fisheries activity,

454 mostly by trawlers, occurs (Léauté, 1998). Thus, this vast area may well serve as a trap for

455 products sinking from the diatom late winter bloom that occurs in the distal plume of the

456 Loire river (Gohin et al., 2003). Lateral transport from higher on the shelf also may be

457 important, playing the role of a kind of rack for feeding of fishes inhabiting the immediate

458 vicinity.

459

460 4.2. Ecological regionalism of the Bay of Biscay 
461 In this study, we found substantial differences in the levels of both metabolic descriptors

462 and ecological processes at different sites in the Bay of Biscay. It is important to keep in

463 mind, however, that the depths of sampling stations ranged from 15-20 $\mathrm{m}$ in estuary

464 mouths to more than $200 \mathrm{~m}$ over and beyond the shelf break. If one accepts the

465 assumptions presented in the introduction inherent in the use of our metabolic assessment

466 tools as proxies for the main processes involved in the functioning of mesozooplankton

467 communities, then our data lead us to propose the following spatial compartmentalization.

\subsubsection{Estuaries and marine areas under their influence}

470 Outflow rates of the two large estuaries responsible for an enrichment in nutrients along 471 the continental shelf are similar (i.e., slightly higher than $10^{3}$ (around 1200) $\mathrm{m}^{3} \mathrm{~s}^{-1}$; Anne-

472 Marie Jegou, Dept. DYNECO, IFREMER, pers. comm.). Moreover, they do not differ in 473 either the extent of low surface salinity or high nitrate concentrations. Nevertheless, we 474 found great differences in trypsin and ATC specific activities between the Loire and the 475 Gironde estuaries. Differences in abundance of particulate organic carbon are patent and 476 might explain why trypsin activity in mesozooplankton was higher in water flowing out

477 from the Gironde. ATC activities in this same area also were among the highest measured 478 in our study, which indicates a strong mesozooplankton productivity potential. Therefore, 479 this site seemed to be characterized not by a classical (i.e., based on primary production) 480 food chain but by an efficient short food chain in which protein-rich particulate matter 481 constituted the main food source for an actively growing mesozooplankton community; 482 this community, in turn, is of benefit to breeding anchovies. This difference between the 483 Loire and Gironde estuaries' attractive effect on anchovy biomass has been studied 484 annually for many years, but the following question remains: Why are anchovies almost never present near the Loire estuary? Even if the particulate matter brought by the Gironde 
has a different nutritive value, it is more abundant and the results from our study bring

487 substantial elements for the coherence of this observation.

488

\subsubsection{La Grande Vasière, the silt-rich region}

490 Small-sized phytoplankton cells dominate in the northern-central part of the continental

491 shelf. The limitation in nutrients in this area favours the development of an active

492 microbial loop and creates conditions for high production of both particulate and dissolved carbohydrates, which induces an enhancement of PK activity in mesozooplankton.

However, we found no evidence for increased ATC activity. The relatively intense

biological activity within the superficial layers of the water, indicated by the high PK activities, likely is beneficial to the underlying muddy seafloor that is well known for the abundance of its benthic fauna.

498

\subsubsection{The continental slope}

500 Along the shelf break, strong tidally induced internal waves provide a nutrient supply to

501 the surface layers via up-welling. Thus, higher phytoplankton biomass (Chl. $a$ ) indicates

502 most probably that the primary productivity is enhanced and it is used by the sardine

503 population. The strongest effects of these internal waves occur in the Celtic Sea, in front of

504 the entrance of the English Channel, a region located just at the northwestern limit of our

505 sampling area in the Bay of Biscay; there is a decreasing trend in these effects towards the

506 southeastern part of the bay. Enzyme activities measured in this study seemed to reflect

507 this trend: The high trypsin activities found at the northwest limit likely are evidence of a

508 massive supply of protein-rich matter, then high PK activities (three stations corresponding

509 with a core of nitrates in Figure 3) were found, followed by a decrease when moving to the

510 SE. 
512 4.2.4. The southern region of the Bay of Biscay

513 Large $(>20 \mu \mathrm{m})$ phytoplankton cells inhabit the southern region of the bay. The moderate

514 or high activities of either PK or trypsin found in this area indicate the presence of a

515 classical food chain, in which the balance between carbohydrate and protein as the

516 dominant cell content varies from one station to the other. Along the coast, where surface

517 water is less saline, both trypsin and ATC specific activities had high values. Clearly,

518 environmental conditions encountered along this southern part of the coast and continuing

519 until the northern limit of less saline water out flowing from the Gironde, appear

520 favourable to high mesozooplankton productivity. These conditions exert an evident

521 attractive power on the anchovy population, which needs to feed actively in order to

522 maintain fecundity throughout the breeding season.

523

524

4.3. Established from literature and promising perspectives

525 The relationships between variations in activities of the three enzymes studied in the

526 mesozooplankton and the descriptors of environmental conditions, both abiotic and biotic,

527 are not always simple. Particulate matter (bacteria, microprotozoans, and phytoplankton)

528 and mesozooplankton communities have complex composition, behaviour, distribution,

529 and abundance at multiple spatial and temporal scales (Link et al., 2005). Furthermore,

530 great differences exist in generation times between microbial cells (a few hours to a day,

531 not much more) and the main components of mesozooplankton communities (i.e., for

532 copepods, most often several weeks). The generation time of most species of copepods fits

533 in generally well with the duration of the mesoscale events that influence ecosystem

534 functioning, and this temporal agreement could be very important for a better

535 comprehension of the real natural processes. For instance, storage of carbohydrates such as 
$536 \quad \beta-1,3$ glucan in a phytoplankton cell varies on a temporal scale of a few hours (e.g.

537 between $17 \%$ and $42 \%$ of cellular organic C in a marine diatom species: Granum et al., 538 2002), which means that a C:N ratio determined in such a cell in the evening would not be

539 the same as that determined the preceding morning. It is very unlikely, if not impossible,

540 that copepod cells could adapt their PK activity to such a high frequency variation because

541 there is a latent period between the ingestion of the phytoplankton cell and its assimilation

542 (Mayzaud and Poulet, 1978) through the adaptation of digestive enzyme activities involved

543 in the assimilation of crude molecules of carbohydrates and requiring a time-lag period for

544 acclimatization to quantitative or qualitative change in available prey (Roche-Mayzaud et

545 al., 1991; Mayzaud et al., 1992); therefore, high frequency phenomena tend to be smoothed

546 at the mesozooplankton level of the organization of pelagic ecosystems. As a consequence,

547 the following assumption might be boldly conceived: the indices of mesozooplankton

548 community metabolism most probably provide the best view of the basic processes

549 essentially involved in the functioning of the pelagic ecosystem at the mesoscale.

550

551

552

553

554

555

556

557

558

559

560 


\section{Acknowledgements}

The authors are greatly indebted to several colleagues of the EMH Department: Paul Bourriau and Daniel Halgand for their help in field sampling and sample processing; Nathalie Schreiber for carrying out biochemical analyses. We thank Francis Gohin (IFREMER, Centre de Brest) for providing a remote sensing image of the sea surface Chl a. We are also most grateful for comments from anonymous reviewers that significantly improved the manuscript. Thanks are due to Jacques Massé, manager of the IFREMER Project "Ecologie des Petits Pélagiques", and to the captain, officers, and crew of the RV Thalassa. This study was conducted within the framework of the FOREVAR Project, a French contribution to the GLOBEC (SPACC) International Programme. It was also carried out with the financial support of the French "Programme National d'Ecologie Côtière"/atelier Gascogne (PNEC- Gascogne), and the fisheries research part of the survey was partially financed by the European Commission, DG XIV, under the research project PELASSES n99/010. 


\section{References}

Albaina, A., Irigoien, X., 2004. Relationships between frontal structures and zooplankton communities along a cross-shelf transect in the Bay of Biscay (1995 to 2003). Marine Ecology Progress Series 284, 65-75.

Albaina, A., Irigoien, X., 2007. Fine scale zooplankton distribution in the Bay of Biscay in spring 2004. Journal of Plankton Research 29, 851-870.

Alderkamp, A.-C., Nejstgaard, J. C., Verity, P. G., Zirbel, M. J., Sazhin, A. F., van Rijssel, M., 2006. Dynamics in carbohydrate composition of Phaeocystis pouchetii colonies during spring blooms in mesocosms. Journal of Sea Research 55, 169-181.

Arbault, S., Lacroix, N., 1977. Oeufs et larves de clupéidés et engraulidés dans le Golfe de Gascogne (1969-1973). Distribution des frayères. Relations entre les facteurs du milieu et la reproduction. Revue des Travaux de l'Institut des Pêches Maritimes 41, 227-254.

Artigas, L. F., 1998. Seasonal variability in microplanktonic biomasses in the Gironde dilution plume (Bay of Biscay): relative importance of bacteria. Oceanologica Acta 21, 563-580.

Båmstedt, U., 1988. Interspecific, seasonal and diel variations in zooplankton trypsin and amylase activities in Kosterfjorden, western Sweden. Marine Ecology Progress Series 44, 15-24.

Banse, K., 1995. Zooplankton: Pivotal role in the control of ocean production. ICES Journal of Marine Science 52, 265-277.

Bergeron, J.-P., 1983. Approche systémique des potentialités de production secondaire pélagique: l'évolution printanière en province néritique. Oceanologica Acta vol. spé. $\mathrm{n}^{\circ} 4,15-19$.

Bergeron, J.-P., 1986. Approche systémique des potentialités de production secondaire pélagique: inférences de fluctuations interannuelles. Oceanologica Acta 9, 291-303.

Bergeron, J.-P., 1995. Aspartate transcarbamylase activity for the assessment of mesozooplankton production: new aspects from oceanic areas. ICES Journal of Marine Science 52, 305-313.

Bergeron, J.-P., 2004. Contrasting years in the Gironde estuary (Bay of Biscay, NE Atlantic) springtime outflow and consequences for zooplankton pyruvate kinase activity and the nutritional condition of anchovy larvae: an early view. ICES Journal of Marine Science 61, 928-932.

Bergeron, J.-P., 2006. Small-scale variability of zooplankton pyruvate kinase activity in the Gironde Estuary plume (Atlantic French Coast): a case study under unusually low freshwater discharge. Estuarine, Coastal and Shelf Science 69, 662-666.

Bergeron, J.-P., Alayse-Danet, A.-M., 1981. Aspartate transcarbamylase de la coquille Saint-Jacques Pecten maximus L. (Mollusque Lamellibranche): méthode de dosage et variations de l'activité dans le manteau et la gonade. Journal of Experimental Marine Biology and Ecology 50, 99-117.

Bergeron, J.-P., Herbland, A., 2001. Pyruvate kinase activity as index of carbohydrate assimilation by mesozooplankton: an early field implementation in the Bay of Biscay, NE Atlantic. Journal of Plankton Research 23, 157-163.

Berges, J. A., Roff, J. C., Ballantyne, J. S., 1993. Enzymatic indices of respiration and ammonia excretion: relationships to body size and food levels. Journal of Plankton Research 15, 239-254.

Biegala, I. C., Bergeron, J.-P., 1998. Optimal assay conditions for aspartate transcarbamylase (ATCase) activity in mesozooplankton. Journal of Plankton Research 20, 1205-1218. 
Børsheim, K. Y., Vadstein, O., Myklestad, S. M., Reinertsen, H., Kirkvold, S., Olsen, Y., 2005. Photosynthetic algal production, accumulation and release of phytoplankton storage carbohydrates and bacterial production in a gradient in daily nutrient supply. Journal of Plankton Research 27, 743-755.

Boucher, J., Laurec, A., Samain, J.-F., Smith, S. L., 1976. Etude de la nutrition, du régime et du rythme alimentaire du zooplancton dans les conditions naturelles par la mesure des activités enzymatiques digestives. In: Proceedings of the 10th European Marine Biology Symposium, Vol. 2, Persoone, G., Jaspers, E. (Eds.). Universa Press, Wetteren, Belgium, pp. 85-110.

Bücher, T., Pfleiderer, G. 1955. Pyruvate kinase from muscle. In: Clowick, S.P., Kaplan, N.O. (Eds.) Methods in enzymology, vol.1. Academic Press, London, pp 435-440

Castel, J., Feurtet, A., 1989. Dynamics of the copepod Eurytemora affinis hirundoides in the Gironde estuary: Origin and fate of its production. Scientia Marina 53, 577-584.

Cho, B. C., Azam, F., 1990. Biogeochemical significance of bacterial biomass in the ocean's euphotic zone. Marine Ecology Progress Series 63, 253-259.

David, V., Sautour, B., Chardy, P., Leconte, M., 2005. Long-term changes of the zooplankton variability in a turbid environment: The Gironde estuary (France). Estuarine, Coastal and Shelf Science 64, 171-184.

Garrido, S., Marçalo, A., Zwolinski, J., van der Lingen, C. D., 2007. Laboratory investigations on the effect of prey size and concentration on the feeding behaviour of Sardina pilchardus. Marine Ecology Progress Series 330, 189-199.

Gasparini, S., Castel, J., Irigoien, X., 1999. Impact of suspended particulate matter on egg production of the marine copepod, Eurytemora affinis. Journal of Marine Systems 22, 195-205.

Gohin, F., Lampert, L., Guillaud, J.-F., Herbland, A., Nézan, E., 2003. Satellite and in situ observations of a late winter phytoplankton bloom in the northern Bay of Biscay. Continental Shelf Research 23, 1117-1141.

Gohin, F., Loyer, S, Lunven, M., Labry, C., Froidefond, J.-M., Delmas, D., Huret, M., Herbland, A., 2005. Satellite-derived parameters for biological modelling in coastal waters: Illustration over the eastern continental shelf of the Bay of Biscay. Remote Sensing of Environment 95, 29-46.

Granéli, E., Carlsson, P., Turner, J. T., Tester, P. A., Béchemin, C., Dawson, R., Funari, E., 1999. Effects of N:P:Si ratios and zooplankton grazing on phytoplankton communities in the northern Adriatic Sea. 1. Nutrients, phytoplankton biomass, and polysaccharide production. Aquatic Microbial Ecology 18, 37-54.

Granum, E., Kirkvold, S., Myklestad, S. M., 2002. Cellular and extracellular production of carbohydrates and amino acids by the marine diatom Skeletonema costatum: diel variations and effects of N depletion. Marine Ecology Progress Series 242, 83-94.

Håkanson, L., 2006. The relationship between salinity, suspended particulate matter and water clarity in aquatic systems. Ecological Research 21, 75-90.

Haug, A., Myklestad, S., Sakshaug, E., 1973. Studies on the phytoplankton ecology of the Trondheimsfjord. I. The chemical composition of phytoplankton populations. Journal of Experimental Marine Biology and Ecology 11, 15-26.

Heinle, D. R., Harris, R. P., Ustach, J. F., Flemer, D. A., 1977. Detritus as food for estuarine copepods. Marine Biology 40, 341-353.

Hirche, H.-J., 1989. Spatial distribution of digestive enzyme activities of Calanus finmarchicus and C.hyperboreus in Fram Strait/Greenland Sea. Journal of Plankton Research 11, 431-443. 
Irigoien, X., Castel, J., 1995. Feeding rates and productivity of the copepod Acartia bifilosa in a highly turbid estuary: the Gironde (SW France). Hydrobiologia 311, 115-125.

Léauté, J.-P., 1998. Les flotilles de pêche de l'Union Européenne dans le Golfe de Gascogne vues du ciel. Oceanologica Acta 21, 371-381.

Legendre, L., Rassoulzadegan, F., 1995. Plankton and nutrient dynamics in marine waters. Ophelia 41, 153-172.

Link, J. S., Stockhausen, W. T., Methrata, E. T., 2005. Food-webs theory in marine ecosystems. In: Belgrano, A., Scharler, U.M.,Dunne, J., Ulanowicz, R.E. (Eds.), Aquatic Food Webs, An Ecosystem Approach. Oxford University Press Inc., New York, pp. 98-113.

Lischka, S., Giménez, L., Hagen, M., Ueberschär, B., 2007. Seasonal changes in digestive enzyme (trypsin) activity of the copepods Pseudocalanus minutus (Calanoida) and Oithona similis (Cyclopoida) in the Arctic Kongsfjorden (Svalbard). Polar Biology 30, 1331-1341.

Mauchline, J. 1998. The biology of calanoid copepods. Advances in Marine Biology 33, 1710.

Mayzaud, P., 1986. Digestive enzymes and their relation to nutrition. In: Corner, E.D.S., O'Hara, S.C.M. (Eds.), The biological chemistry of marine copepods. Clarendon Press, Oxford, pp. 165-225.

Mayzaud, P., Poulet, S. A., 1978. The importance of the time factor in the response of zooplankton to varying concentrations of naturally occurring particulate matter. Limnology and Oceanography 23, 1144-1154.

Mayzaud, P., Roche-Mayzaud, O., Razouls, S., 1992. Medium term time acclimation of feeding and digestive enzyme actvitiy in marine copepods: influence of food concentration and copepod species. Marine Ecology Progress Series 89, 197-212.

Packard, T. T., Berdalet, E., Blasco, D., Roy, S. O., St-Amand, L., Lagacé, B., Lee, K., Gagné, J.-P. 1996. Oxygen consumption in the marine bacterium Pseudomonas nautica predicted from ETS activity and bisubstrate enzyme kinetics. Journal of Plankton Research 18, 1819-1835.

Petitgas, P., Massé, J., Bourriau, P., Beillois, P., Bergeron, J.-P., Delmas, D., Herbland, A., Koueta, N., Froidefond, J.-M., Santos, M., 2006. Hydro-plankton characteristics and their relationship with sardine and anchovy distributions on the French shelf of the Bay of Biscay. Scientia Marina 70S1, 161-172.

Planque, B., Lazure, P., Jegou, A. M. 2006. Typology of the hydrological structures modelled and observed over the Bay of Biscay shelf. Scientia Marina 70S1, 43-50.

Plounevez, S., Champalbert, G., 1999. Feeding behaviour and trophic environment of Engraulis encrasicolus (L.) in the Bay of Biscay. Estuarine, Coastal and Shelf Science 49, 177-191.

Poulet, S. A., 1976. Feeding of Pseudocalanus minutus on living and non-living particles. Marine Biology 34, 117-125.

Roche-Mayzaud, O., Mayzaud, P., Biggs, D. C., 1991. Medium-term acclimation of feeding and of digestive and metabolic enzyme activity in the neritic copepod Acartia clausi. I. Evidence from laboratory experiments. Marine Ecology Progress Series 69, 25-40.

Samain, J.-F., Daniel, J.-Y., Le Coz, J.-R., 1977. Trypsine, amylase et protéines du zooplancton: dosage automatique et manuel. Journal of Experimental Marine Biology and Ecology 29, 279-289.

Scalabrin, C., Massé, J., 1993. Acoustic detection of the spatial and temporal distribution of fish shoals in the Bay of Biscay. Aquatic Living Resources 6, 269-283. 
Sieburth, J. McN., Smetacek, V., Lenz, J., 1978. Pelagic ecosystem structure: Heterotrophic compartments of plankton and their relationship to plankton size fraction. Limnology and Oceanography 23, 1256-1263.

Simon, M., Cho, B. C., Azam, F., 1992. Significance of bacterial biomass in lakes and the ocean: comparison to phytoplankton biomass and biogeochemical implications. Marine Ecology Progress Series 86, 103-110.

Steele, J.H., Ed., 1977. Spatial pattern in plankton communities. Plenum Press. New-York and London. $470 \mathrm{pp}$.

Tackx, M., Irigoien, X., Daro, N., Castel, J., Zhu, L., Zhang, X., Nijs, J., 1995. Copepod feeding in the Westerschelde and the Gironde. Hydrobiologia 311, 71-83.

Whitfield, J., 2004. Ecology's big, hot idea. PLoS Biology 2, 2023-2027.

Williamson, S. W., Favuzzi, J., Cox, J.L., 1986. Patchiness and nutritional condition of zooplankton in the California Current. Fishery Bulletin 84, 157-176. 


\section{Figure captions}

Figure 1

Map of the stations sampled in the Bay of Biscay. Black dots represent stations where all $\mathrm{t}$ the operations were carried out, open symbols indicate stations where only vertical temperature and salinity profiles were recorded and mesozooplankton samples were collected. The dotted line over the shelf break shows approximately the location of the chlorophyll section presented in Figure 4.

Figure 2

Map of the spatial variation of salinity in surface waters (numbers outside of the frame are indicative of geographic coordinates).

Figure 3

Map of the spatial variation in surface waters of nitrate concentrations expressed in $\mu \mathrm{M}^{-1}$ (numbers outside of the frame are indicative of geographic coordinates).

Figure 4

Remote sensing of sea surface $\mathrm{Chl}$ a and vertical section (following the dotted line presented in Figure 1) over the shelf break showing measured $\mathrm{Chl}$ a concentrations expressed in $\mu \mathrm{g}^{-1}$ according to depth ( $\mathrm{Z}$ in $\mathrm{m}$ )

Figure 5

Map showing spatial variation of three main size classes in $\%$ of phytoplankton cells (integrated values through the photic layer, numbers outside of the frame are indicative of geographic coordinates).

Figure 6

Map showing the spatial variation of the ratio (microbial C)/POC (integrated values through the photic layer). Three numbers in larger and bold type are mean values for four stations in less saline water obviously issuing from each of the three rivers (the numbers outside of the frame are indicative of geographic coordinates).

Figure 7

Map of the spatial variation of the ratio (bacterial C)/(phytoplankton C), values integrated through the photic layer (numbers outside of the frame are indicative of geographic coordinates). Note similarities with the spatial variations of PK specific activities shown in Figure 8a. 
Figure 8

Spatial distribution of values of the three enzymatic specific activities (see "Material and methods" section for definitions) measured in samples of the whole mesozooplankton communities, PK (a), trypsin (b) and ATC (c). Both 200 and 500 $m$ depths isobaths indicate the limits of the continental shelf.

Figure 9

Abundance and spatial distribution of the populations of the two main fish species representing a trophic level just above mesozooplankton in the Bay of Biscay: anchovy (Engraulis encrasicolus) in grey on the left and sardine (Sardina pilchardus) in white on the right (Jacques Massé, Dept. EMH, IFREMER, pers. comm.). Varying sizes of symbols are proportional to estimated fish biomass expressed in tonnes nautical mile ${ }^{-2} .50,100$ and $200 \mathrm{~m}$ depths isobaths are shown. 


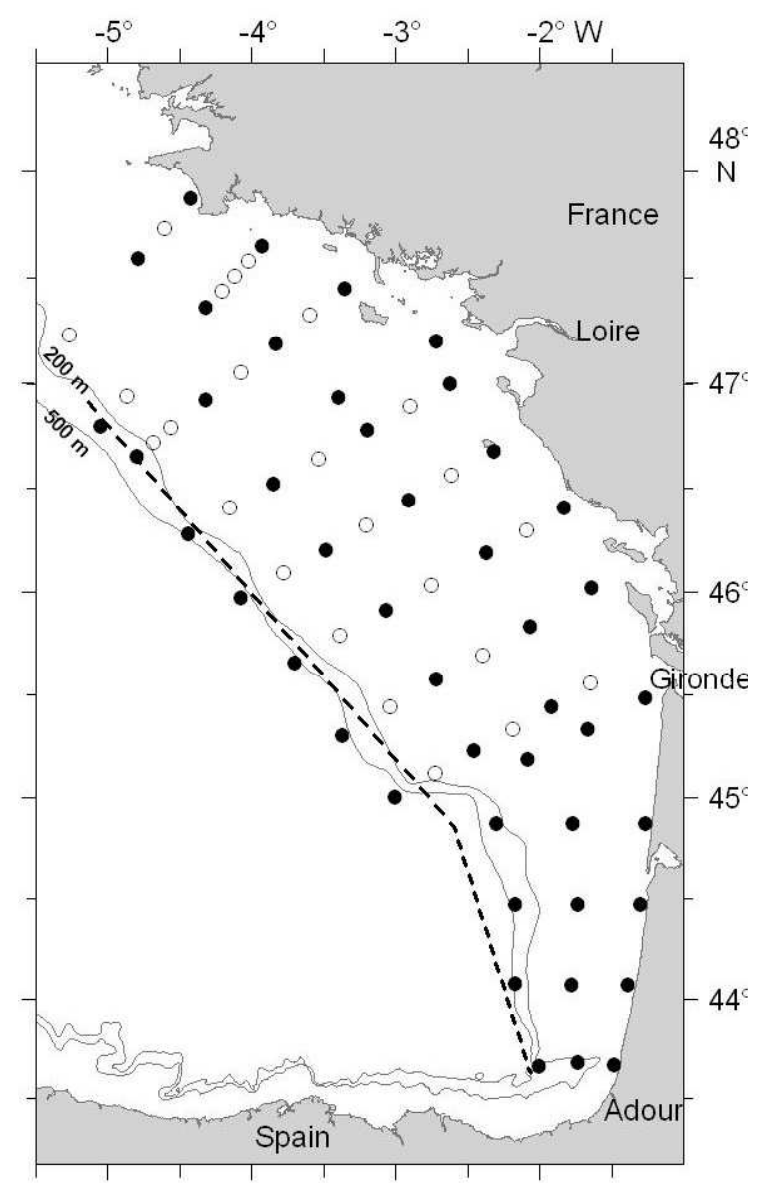




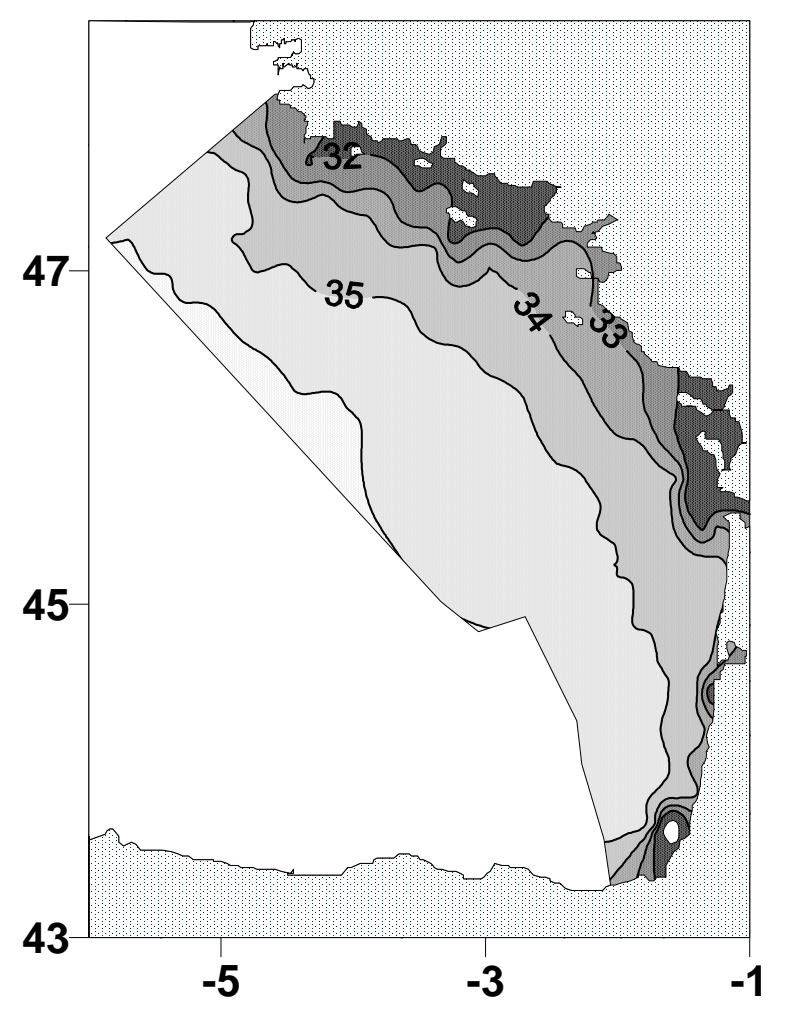

Fig 2

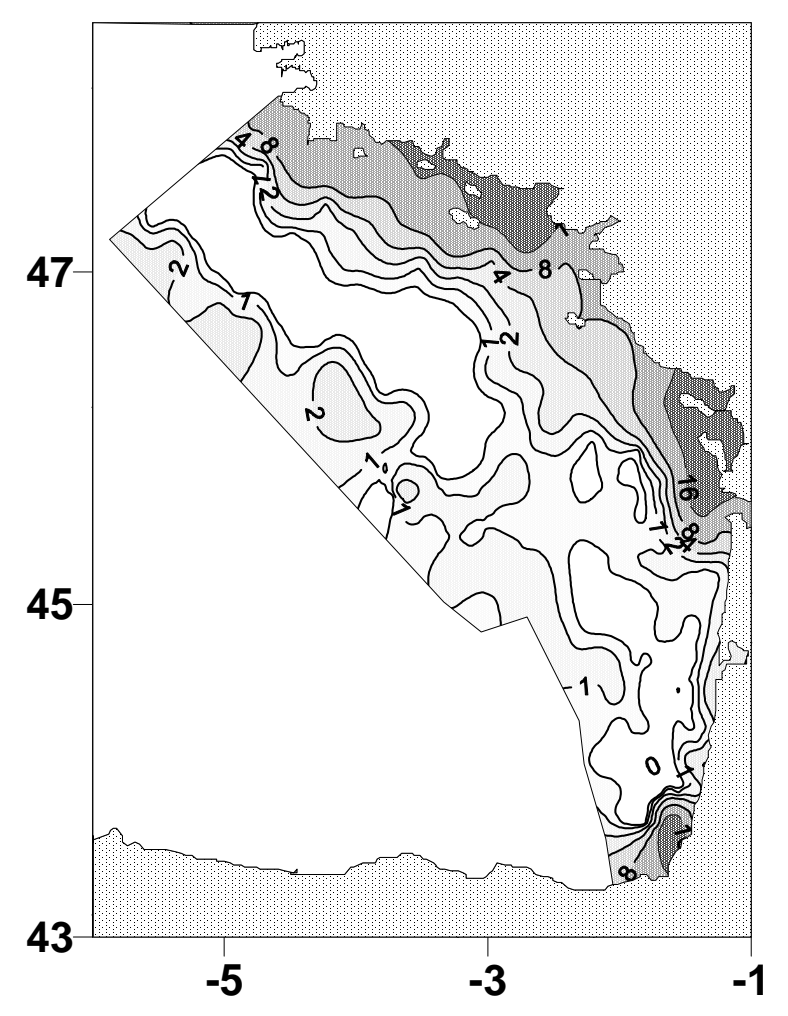

Fig 3 
Fig 4

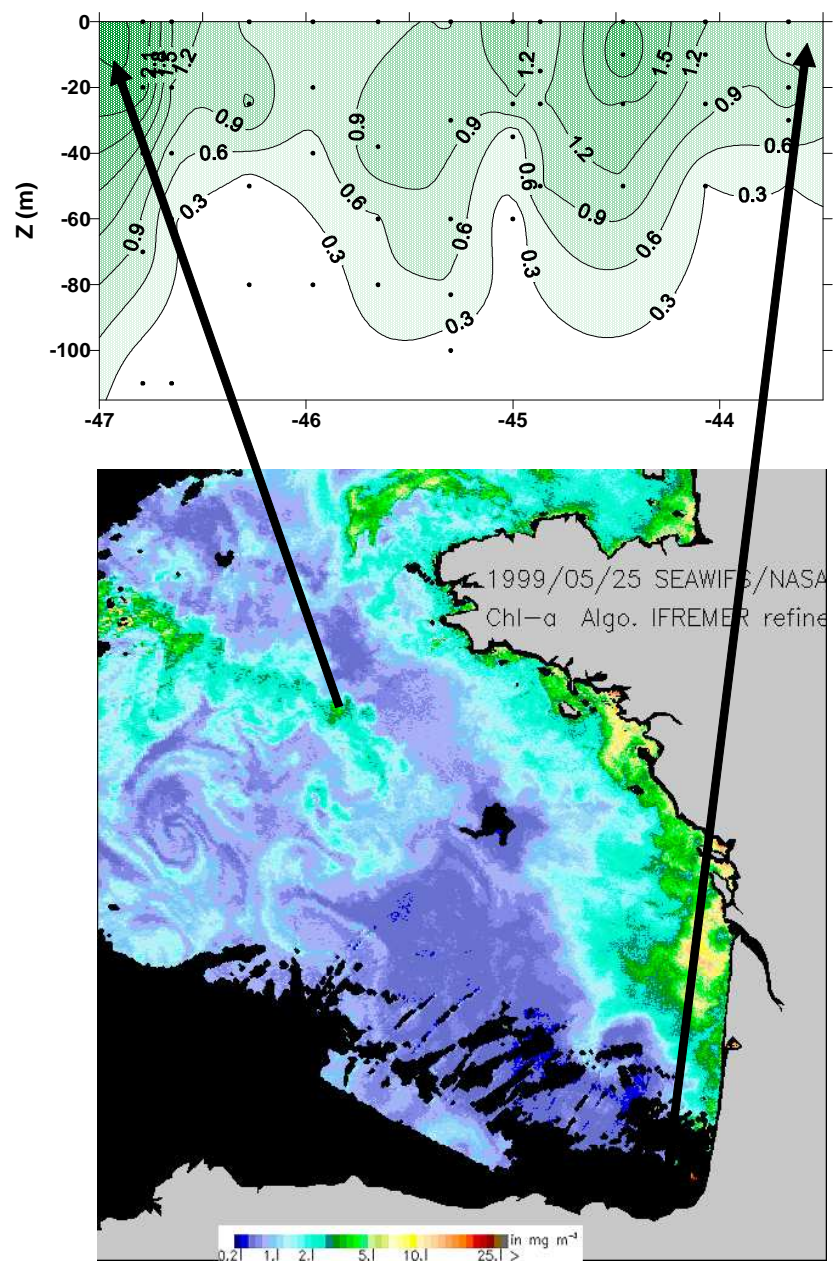



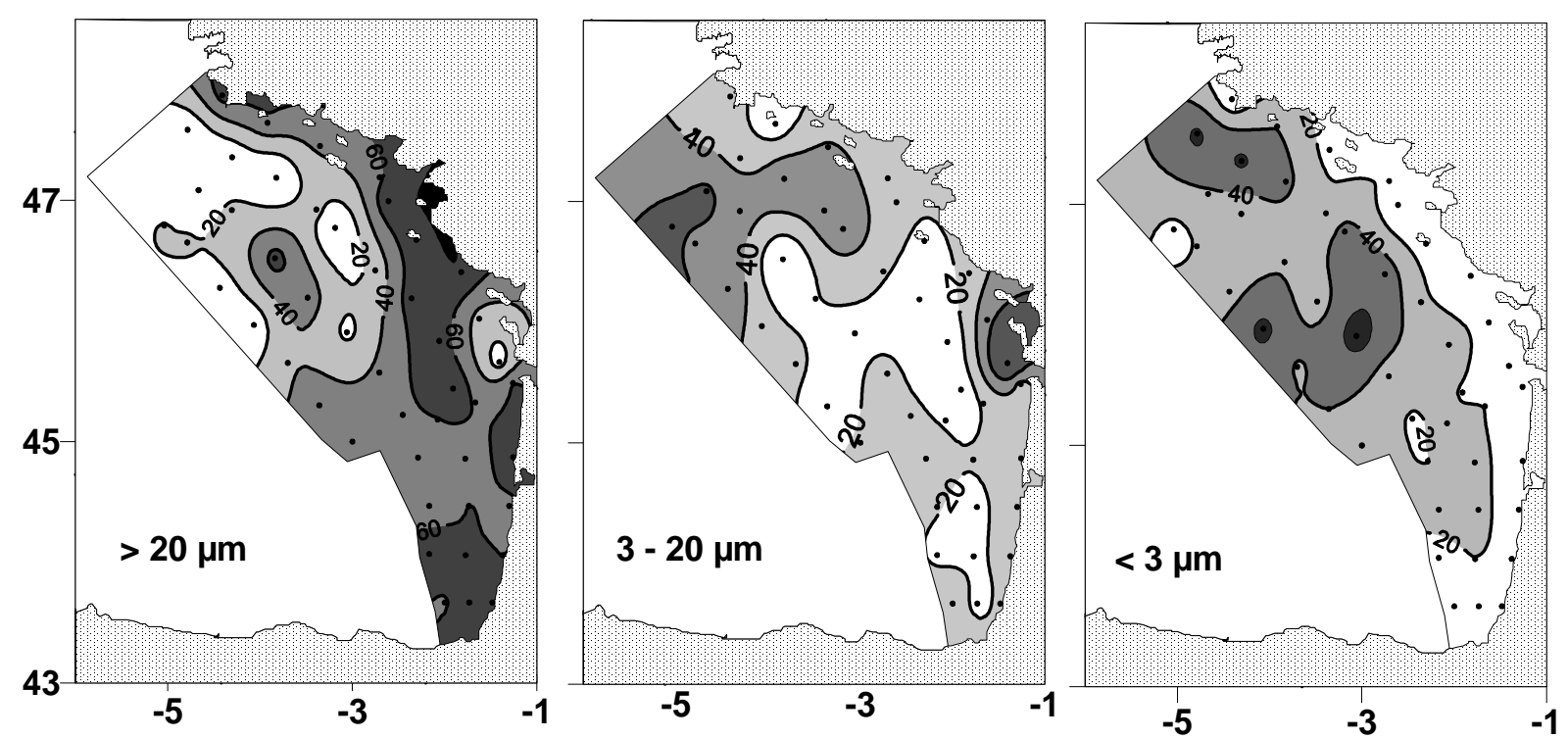

Fig 5

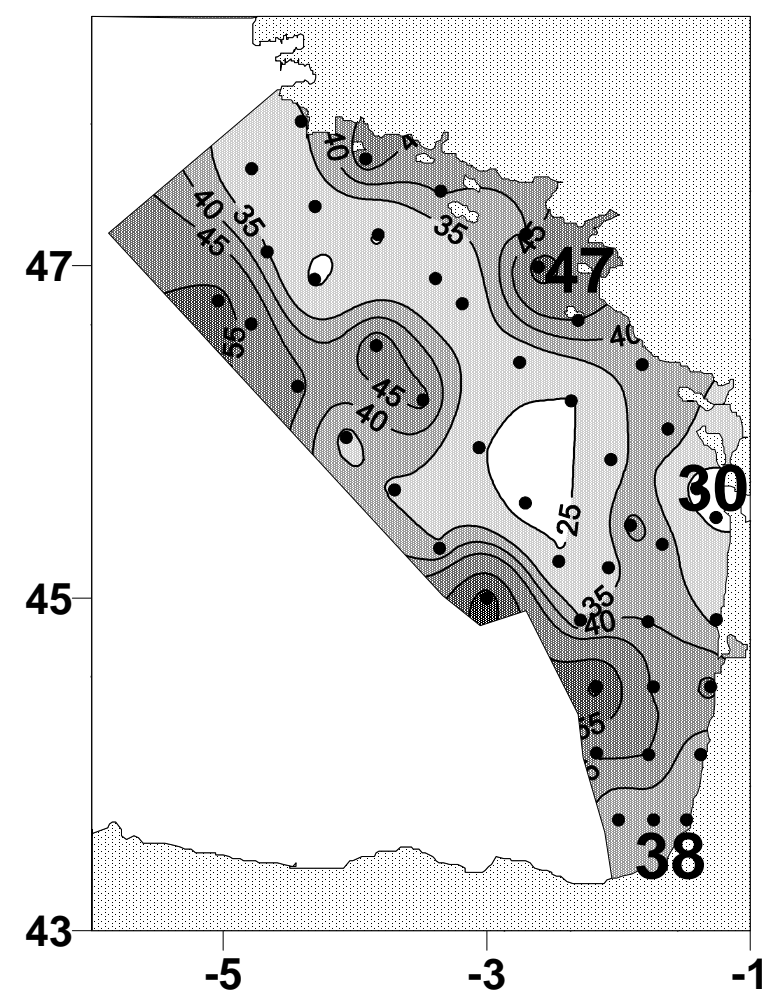

Fig 6 


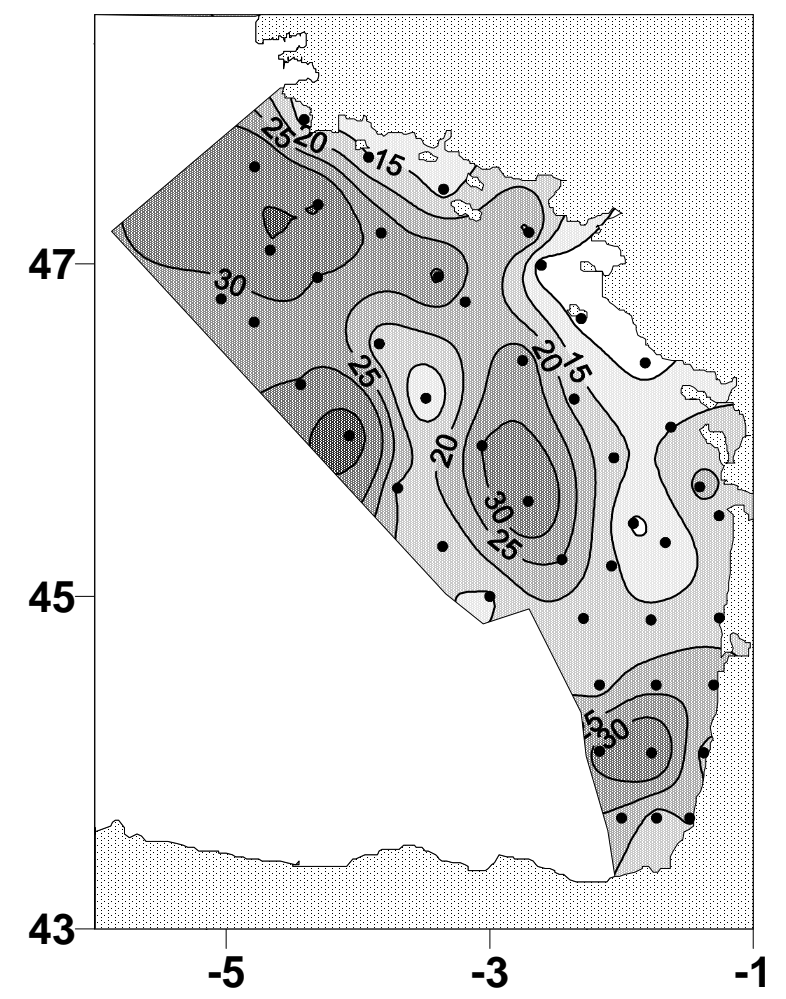

Fig 7 

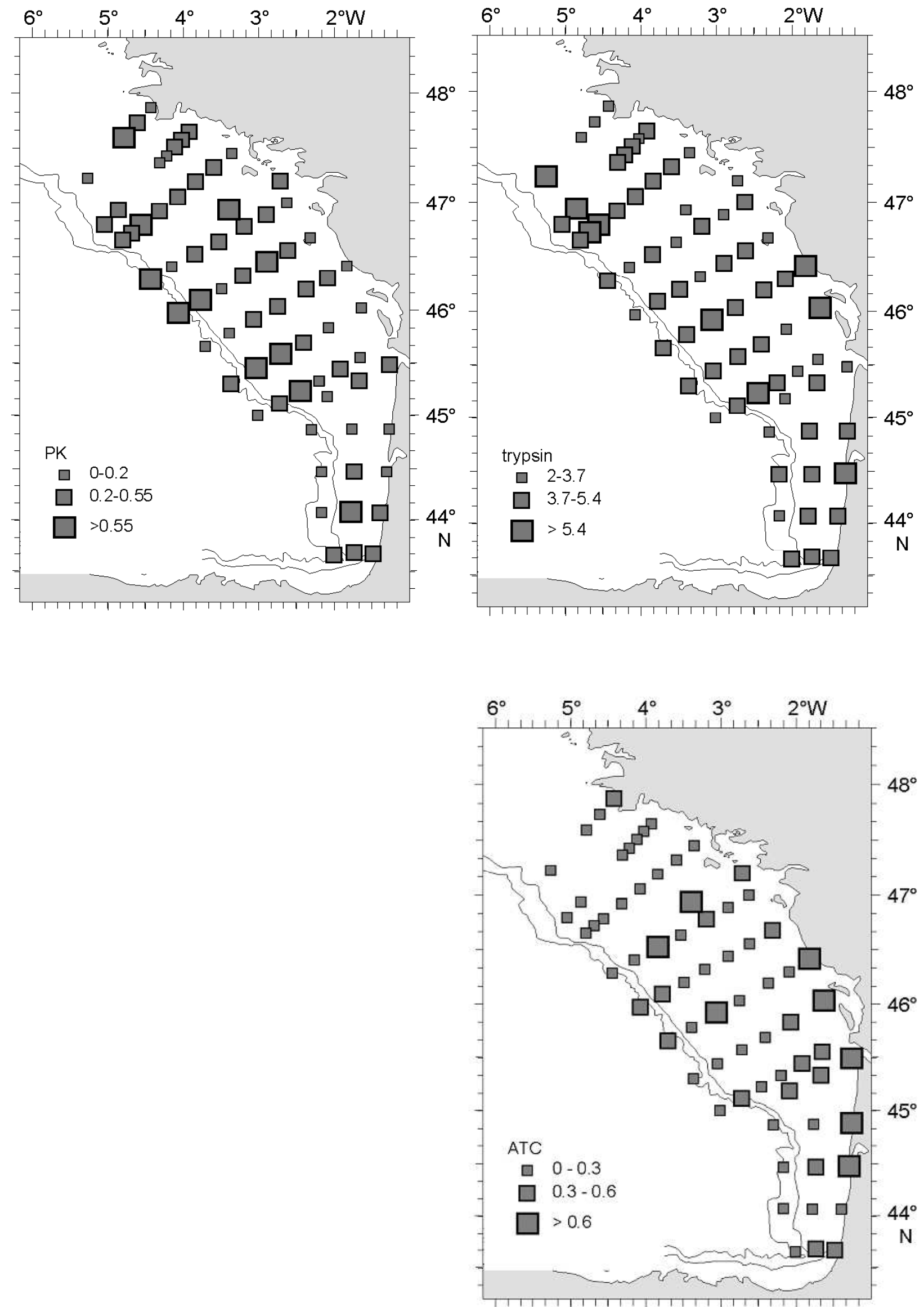

Fig 8 

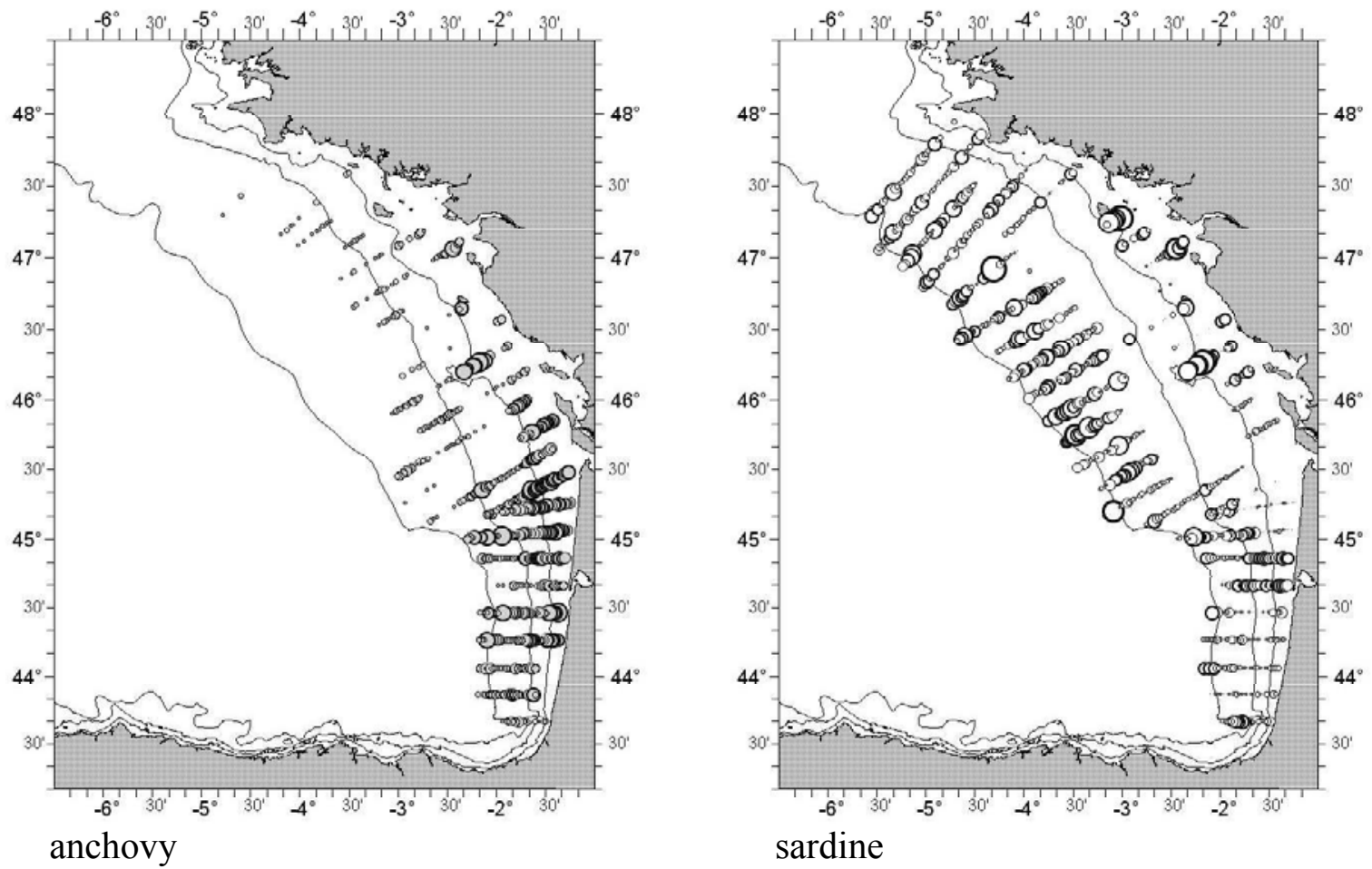

Fig 9 